\title{
Gugon Tuhon in Serat Tata Cara: The Myth of Dietary Recommendation and Restrictions for Pregnant Women
}

\author{
Riza Rahmawati ${ }^{1}$, Turita Indah Setyani ${ }^{2}$ \\ \{rahmariza16@gmail.com ${ }^{1}$,turita.indah@ui.ac.id $\left.{ }^{2}\right\}$
${ }^{1}$ Sastra Daerah for Javanese Literature, Faculty of Humanities, Universitas Indonesia, Indonesia.
${ }^{2} \mathrm{Ilmu}$ Susastra, Faculty of Humanities, Universitas Indonesia, Indonesia.

\begin{abstract}
During pregnancy, women are likely to gain knowledge on recommended and restricted foods, called as gugon tuhon, ruled according to the cultural environment. Several of the recommendations and restrictions are considered irrational in modern society. This article is aimed at revealing the meaning of gugon tuhon for pregnant women in the form of dietary recommendations and restrictions written in Serat Tata Cara by Ki Padmasusastra. The analysis combines qualitative method with Paul Ricoeur's hermeneutics theory and the concept of myth by Mircea Eliade to interpret messages embedded in literary works by cultural approach. Analysis results show that there are several dietary recommendations and restrictions for pregnant women in Javanese society. Gugon tuhon is constructed by the Javanese as a form of traditional surveillance. It represents some aspects of Javanese traditions still maintained until today. This article concludes that the dietary recommendations and restrictions for pregnant women are cannot be considered as mere myth as it can be explained in rational sense or read as the rationalization of the Javanese philosophy.
\end{abstract}

Keywords:dietary recommendations and restrictions, gugon tuhon,pregnant women, Serat Tata Cara

\section{INTRODUCTION}

Each society has its own cultural custom in responding the stages in human life. Koentjaraningrat reveals that many ethnic groups believe that each development from one life stage to another is a critical period, and customary ceremonies are required to resist threatening dangers for individuals from the environment.[1].Customary ceremony is believed to provide safety for the performers. Meanwhile, several societies are not only performing traditional ceremonies, as in the case of pregnant women where the society requires them to follow certain recommendations and restrictions during her pregnancy. It can be in the form of dietary and behavioral recommendations and restrictions.

Pregnant women are likely to get recommendations and restrictions from their surroundings. They tend to follow the recommendations and restrictions with future 
consequences in consideration. The regulation for pregnant women is maintained by several ethnic groups in the world. The Indian culture restricts food consumption and physical mobility for pregnant women, while at the same time orders them to be faithful to their husbands[2].Meanwhile, southeast Madagascar people believe that consuming herbal medicine will improve the health of pregnant women and their fetus[3]. In Europe, the Romanian maintain traditional customs in women's pregnancies and deliveries[4]. The recommendations and restrictions for pregnant women are varied among different regions and cultures. However, it implies significant influence towards women in particular[5].

Javanese culture also acknowledges the recommended and restricted foods for pregnant women as delivered in Serat Tata Cara written by Ki Padmasusastra. Serat Tata Cara is written in 1863, in Betawi, and completed in 1904, in Surakarta, then published by Kangjeng Gupremen of Betawi in 1907. This prose describes the recommendations and restrictions in the form of dialogues between family members. The manuscript is not only providing recommendations and restrictions for pregnant women, but also explaining the ritual and ceremony procedures for commemorating traditional life cycles in Javanese sense.

There has been an ongoing academic interest on traditional views and customs of maternity. In 2003, Maria Irene and Edgar V studied the restricted foods for pregnant women in Mexican culture with the title Food Taboos among Nursing Mothers of Mexico. Babila Mutia (2005) examined the practice of pregnancy rituals in her research, Performer, Audience, and Performance Context of Bakweri Pregnancy Rituals and Incantations. Research on Romanian traditional maternity custom was discussed in Romanian Beliefs and Rites of Pregnancy with Special Reference to Moldova by Adina Hulubaş (2011). Later in 2014, Jessica L Moris and Samm Short studied the Malagasy traditional maternal customs under the title Maternal Health Practices, Beliefs and Traditions in Southeast Madagascar.

At the same time, Indonesian scholars have also conducted research on recommendations and restrictions behaviors and foods regulated by local customs. In 2006, Sugeng Priyadi published his research on food and behavior restrictions for pregnant women and behavior restrictions for fathers-to-be, entitled Makna Simbolis Pantangan pada Wanita Hamil di Pedesaan Banyumas. Kasnodihardjo and Lusi Kristiana's Praktek Budaya Perawatan Kehamilan di Desa Gadingsari Yogyakarta (2012) revealed the traditional cultural perspective on dietary recommendations and restrictions, as well as rituals for pregnant women. Muhamad Rofi'i (2013) in his study, Kepercayaan Wanita Jawa tentang Perilaku atau Kebiasaan yang Dianjurkan dan Dilarang selama masa Kehamilan revealed the Javanese women's beliefs during pregnancy. Thesis on the diet and food restrictions for pregnant women and women of the postpartum period was written by Ira Utami Agusputri (2015) under the title Food Taboo dan Agency: Studi Tentang Pantangan Makan bagi Ibu Hamil dan Ibu Masa Nifas di Desa Ciganjeng, Kabupaten Pangandaran, Jawa Barat. In the same year, Ida Untari dan Siti Mayasari (2015) discussed the maternity myth in BPS Zubaidah in their article Study of Developing the Myths of Pregnancy in BPS Zubaidah, provides myth surrounding the pregnant women, especially in BPS Zubaidah. In addition, Kepercayaan dan Praktik Budaya pada Masa Kehamilan Masyarakat Desa Karangsari, Kabupaten Garut (2018) by Juariah described some traditional maternity myths and practices in Karangsari Village.

Despite the ongoing interest on this subject, the dietary recommendations and restrictions in Serat Tata Cara by Ki Padmasusastra have not yet discussed. While in fact, the dietary recommendations and restrictions for pregnant women described in Serat Tata Cara have strong relevance to current, modern life. It is a good example of local wisdom in pregnancy supervision believed by some Javanese communities before the spread of modern maternity 
care techniques. Therefore, this article will provide knowledge for the readers about the Javanese views on pregnancy.

\section{METHOD}

This article applies qualitative research method with the combination of hermeneutics theory by Paul Ricoeur and Mircea Eliade's concept of myth to interpret messages embedded in literary works by cultural approach. Interpretation, according to Ricoeur is the work of thinking that includes the description of the hidden meaning from the visible meaning or the implicit meaning from the explicit depiction[6]. The researcher distance herself with the studied text during the interpretation to allow the discovery of new meaning. Gugon tuhon as a object in this article is tale believed to imply specific consequences or power [7]. Therefore, the research methodology in this paper includes translation, data collection, and message interpretation.

\section{RESULT AND DISCUSSION}

The Javanese believe there are several recommended and restricted foods for pregnant women during the pregnancy. Manuaba revealed the restricted and recommended behaviors and foods during the pregnancy as well as some recommended herbs to be consumed by the pregnant women before the delivery according to the local wisdom[8].Initially, the recommendations and restrictions were inherited through oral tradition. In the later period, some authors began to write it down, as can be read in Serat Tata Cara. It describes one kind of herbal medicine (jamu) to be consumed and four kinds of restricted foods for pregnant women during the first month of pregnancy until the delivery.

Nowadays, most people are no longer following the recommendations and restrictions prevailed in the society as it is considered irrelevant and irrational in modern life. Further analysis on the recommendations and restrictions foods taught by Javanese ancestors showed much rationality of this traditional pregnancy surveillance.

\subsection{Food Recommendation inSerat Tata Cara}

Serat Tata Cara recommends jamucabai lempuyang to be consumed by pregnant women. It is a herbal medicine composed of javanese pepperand bitter ginger.

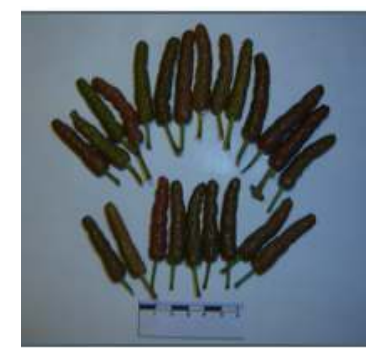

Fig. 1.Javanese pepper Source: Habitus dan Pencirian Tanaman Cabe Jamu by Amin Zuchri

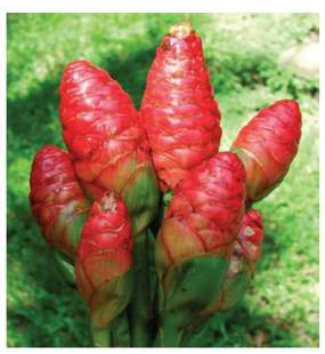

Fig. 2. Bitter ginger Source: Zingiber zerumbet (L.) Smith: A Review of Its Ethnomedicinal, Chemical, and Pharmacological Uses. Hindawi Publishing 
Javanese pepper and bitter ginger are commonly used plantations for jamu ingredients that can be easily obtained from our surroundings. Toxicity test results showed that Javanese pepper and bitter ginger belong to practically non-toxic (PNT) plants or non-poisonous herbs[9].Javanese pepper is also used as a traditional medicine for fever, hypotension, abdominal pain, beriberi, cholerae, non-perspiration and anthelmintic[10].Bitter ginger is used to treat inflammation and cancer.[11]. The combination of Javanese pepper and bitter ginger jamu is useful to treat drowsiness due to severe diarrhea, limb weakness and aches, as well as a laxative for patients with liver disease[12].

Typically, during the first three months of pregnancy, pregnant women will experience decrease in appetite, nausea, and vomiting which might weaken their stamina[13]. Javanese pepper and bitter ginger jamu is considered the proper treatment for that condition. The recipe of this traditional medicine has been inherited for generations, especially among the Javanese. The medical benefits explained above implied that the recommendation has rational reasonings. Further development as well as education on traditional and herbal medication are needed to increase the potency as a solution for public health.

\subsection{Food Restrictions inSerat Tata Cara}

Restrictions or prohibition on foods for pregnant women contains traditional beliefs called as gugon tuhon. Padmosoekotjo in Rahyono (2015) explained gugon tuhon as a conversation or tale believed to imply specific consequences or power[7]. As explained above, there is one kind of recommended consumption for pregnant women in Serat Tata Cara; the Javanese pepper and bitter ginger jати. Meanwhile, there are four food restrictions in the studied text, namely 1) the meat of breech animals; 2) cannibal freshwater fish; 3) the meat of warmblooded animals; and 4) durian and bael fruits.

The Javanese believes that consuming the meat of breech animals will cause breech birth. Breech birth is when a baby is born bottom first instead of head first. It is difficult to prove the reasoning rationally as it only imply associative meaning. There are several factors responsible for breech birth, including macrosomia, premature birth, narrow pelvis, low placenta position, twin birth, and tumor at the birth canal[14].However, the causal effect of consuming the meat of breech animals have not yet studied in medical field.

The second prohibited food for pregnant women in Serat Tata Cara is cannibal freshwater fish, such as snakewater fish. Consuming any cannibal fish is believed to cause the fetus gone missing from the uterus. In modern medical view, snakehead is a recommended and a safe food for pregnant women as it composed of protein, fat, calcium, zinc, albumin useful for the development of new cells[15]. This prohibition cannot be understood rationally as it contradicts with the biomedical field of study.

However, both of the explained prohibition can be rationalized according to the Javanese philosophy. The Javanese philosophy is constituted with the reading of symbols and sinamuming samudana, or figurative meanings[16]. Therefore, the meaning of that specific prohibition can only be comprehended by deep feeling and full understanding (tanggap ing sasmita) using the Javanese sense.

The symbolic meaning of the associative relation depicted by the prohibition on consuming breech animals corresponds with Eliade's concept of myth. Traditional communities acknowledged the duality of sky and earth; heaven and hell; chaos and cosmos; and others[17].The duality constituted the view of traditional communities towards life: mênôk as unseen, immaterial world; and gêtîk or material world[17]. It is also applied in Javanese communities and can be found in the concept of sirah (head) and awak (body). Head 
is the symbol of leader that takes control over the human mind and body, and the body itself symbolizes followers. Normal birth implies the ideal function of the head as the main controller for thoughts and behaviors during an individual life. Breech birth is strongly discouraged in Javanese culture as it believed to be a sign for inability to think and behave according to the norms. Therefore, the duality concept of sirah and awak in Javanese culture corresponds with the concept of myth by Eliade.

Javanese culture acknowledges the idea of "sapa nandur bakal ngundhuh"(you reap what you sow). Consuming snakehead is believed to cause the fetus gone missing, which symbolizes cannibalism. The Javanese believes that a fetus is able to listen and identify the surroundings. Therefore, pregnant women are required to behave and think carefully, which include choosing the right food. In addition, the Javanese term for snakehead, kutuk, is associated with a Javanese sayings "kutuk marani sunduk"which means "approaching the danger"; and "kutuk nggendhong kemiri"which means "walking on a treacherous path in luxurious dress". The mentioned sayings imply a message for pregnant women to be careful in behaving and choosing their diets in order to avoid adverse consequences for themselves and their pregnancy.

Pregnant women should also avoid consuming meat of warm-blooded animals such as deer as it is believed to cause hemorrhage especially during late-term pregnancy. Restrictions on venison is also believed among the Sakai ethnic group[18]. Venison is generally rare in Indonesian cuisine even though it contains high rate of protein and zinc with low fat, carbohydrate, and cholesterol compared to beef and goat meat[19]. At the same time, excessive consumption of venison has been associated with high blood pressure, hypertension, and preeclampsia which may harm the pregnancy. Therefore, meat-restricted diet is recommended for pregnant women. The restriction on venison mentioned in Serat Tata Cara is a guideline to avoid pregnant women from possible diseases caused by excessive meat consumption.

Durian and bael are the last prohibited foods for pregnant women to avoid miscarriage. Durian is rich in nutritional values such as high calories, antioxidants (vitamin E and betacarotene), minerals, trace elements (iron, zinc, copper and manganese), sulphur compounds and sugars [20]. Excessive durian consumption has been associated with diabetes, heart attack, and hypertension[20]. In addition, high-calories intake will increase body heat and can be harmful for patients with hypertension [21].In this case, nutrition recommendation of Recommended Dietary Allowances (RDA) is the best available guideline for pregnant women [22].Meanwhile, bael is one fruit that can be easily found in Java. It composed of fat and volatile that contains leinonen [23]. In addition, some parts of the plant including fruit, root, and leave composed of antibiotics, while the branch has been used as fish poisoning [23]. However, the leave has been associated with miscarriages. Therefore, it is strongly prohibited for pregnant women.

The above findings have explained the meaning of gugon tuhon in Serat Tata Cara in the form of dietary recommendations and restrictions. It can be either explained in rational sense or needed to be rationalized according to the Javanese perspective. The Javanese prefers to deliver the message in vague manner which needs further analysis. Symbols that are familiar among the Javanese are commonly used in pituduh (instructions, moral duties) and wewaler (taboo, restriction, prohibition) in the form of traditional sayings valuable for an individual life, especially in building relationships among human beings and with The Creator [24]. The dietary recommendations and prohibitions for pregnant women are the example of traditional pregnancy supervision considered beneficial for the women's and fetus' health[25]. Therefore, 
pregnant women are expected to be careful in behaving, communicating, and also choosing the food intake.

The traditional pregnancy surveillance using recommendations and restrictions is preserved for the sake of the women's and fetuses' health that is agreeable to their beliefs[26]. It has been followed by the community even before the development and spread of modern health system. The Javanese had already constructed their own system of regulation in dealing with life events according to the local cultural perspective [27]. As the surveillance effort can be rationalized according to the Javanese view, the discussion provides knowledge about the Javanese cultural values on the dietary recommendations and restrictions analysed using cultural approach.

\section{CONCLUSION}

Gugon tuhon in the form of dietary recommendations and restrictions for pregnant women in Serat Tata Cara is constructed to achieve certain purposes corresponded with the applied norms. Human beings, as the members of the community, need to discover and learn the life phenomenon. The dietary recommendations and restrictions is a form of Javanese local wisdom constructed to support women's and fetuses' health. Pregnant women are expected to control their behaviors which include avoiding any foods that may disturb the fetus' growth. It has been followed by the community even before the development and spread of modern health system. Therefore, the dietary recommendations and restrictions for pregnant women cannot be simply taken as a myth as it implies rational beneficiary in Javanese cultural context and still relevant until today. Further research on this subject is strongly encouraged to provide more knowledge on Javanese local wisdom.

\section{ACKNOWLEDGEMENT}

This research is fully supported by Hibah Publikasi Internasional Terindeks Mahasiswa Magister 2019-2020 funded by DRPM Universitas Indonesia No. NKB0998/UN2.R3.1/HKP.05.00/2019.

\section{REFERENCES}

[1] Koentjaraningrat, Beberapa Pokok Antropologi Sosial. Jakarta: Dian Rakyat, 1990.

[2] Aastha Kant, "Indian Sociological Society Experiencing Pregnancy: Negotiating Cultural and Biomedical Knowledge Source,"Sociol. Bull., Vol. 63, No. 2, pp. 247262, 2014.

[3] J. L. Morris, S. Short, L. Robson, and M. S. Andriatsihosena, "Women's Health and Action Research Centre (WHARC) Maternal Health Practices, Beliefs and Traditions in Southeast Madagasca," Afr. J. Reprod. Health, Vol. 18, No. 3, pp. 101-117, 2014.

[4] H. Adina, "Romanian Beliefs and Rites of Pregnancy with Special Reference to Moldova," Folklore, Vol. 122, No. 3, pp. 264-282, 2011.

[5] S. S. Sered, "Husbands, Wives , and Childbirth Rituals," Anthropology, Vol. 22, No. 2, pp. 187-208, 1994.

[6] Anshari, "Hermeneutika Sebagai Teori dan Metode Interpretasi Makna Teks Sastra," Vol. 15, No. 2, pp. 187-192, 2009.

[7] Rahyono, Kearifan Budaya dalam Kata (Edisi 2). Depok: Wedatana Wedya Sastra, 2015. 
[8] I. A. C. Manuaba, I. B. G. F. Manuaba, and I. B. G. Manuaba, Memahami Kesehatan Reproduksi Wanita Edisi 2. Jakarta: Buku Kedokteran EGC, 2009.

[9] A. Agoes and T. Jacob, Antropologi Kesehatan Indonesia. Jakarta: Buku Kedokteran EGC, 1996.

[10] H. Kikuzaki, M. Kawabata, E. Ishida, Y. Akazawa, Y. Takei, and N. Nakatani, "LCMS Analysis and Structural Determination of New Amides from Javanese Long Pepper (Piper retrofractum)," Biosci. Biotechnol. Biochem., Vol. 57, No. 8, pp. 1329-1333, 2009.

[11] N. J. Yob, S. M. Jofrry, M. M. R. M. M. Affandi, L. K. Teh, M. Z. Salleh, and Z. A. Zakaria, "Zingiber zerumbet (L.) Smith: A Review of Its Ethnomedicinal, Chemical, and Pharmacological Uses ," Evidence-Based Complement. Altern. Med., Vol. 2011, pp. 1-12, 2011.

[12] R. Rahmat, Cabai Jawa: Potensi dan Khasiatnya bagi Kesehatan. Yogyakarta: Kanisius, 2003.

[13] M. Huliana, Panduan Menjalani Kehamilan Sehat. Jakarta: Puspa Swara Anggota IKAPI, 2007.

[14] D. Kasdu, Solusi Problem Persalinan. Jakarta: Puspa Swara Anggota IKAPI, 2007.

[15] E. Suprayitno, Misteri Ikan Gabus. Malang: Universitas Brawijaya Press, 2017.

[16] H. Budiono, Simbolisme Jawa. Yogyakarta: Hanindita Graha Widia, 2008.

[17] M. Eliade, The Myth of the Eternal Return: Cosmos and History. Princeton: Princeton University Press, 2018.

[18] D. M. Leslie, "Rusa unicolor (Artiodactyla: Cervidae)," Mamm. Species, Vol. 43, No. 1, pp. 1-30, 2011.

[19] R. J. Hudson, "Are nutritional adaptations of wild deer relevant to commercial venison production?," Vol. 8, No. 2, pp. 266-276, 2019.

[20] M. Jasamai, N. H. Samsudin, N. Azmi, and E. Kumolosasi, "Effects of durian fruit on blood pressure of spontaneously hypertensive rats," Sains Malaysiana, Vol. 47, No. 6, pp. 1221-1226, 2018.

[21] Y. A. Chua, H. Nurhaslina, and S. H. Gan, "Hyperthermic effects of Durio zibethinus and its interaction with paracetamol," Methods Find. Exp. Clin. Pharmacol., Vol. 30, No. 10, p. 739, 2009.

[22] S. Fikawati, S. Ahmad, and K. Khaula, Gizi Ibu dan Bayi. Jakarta: Rajawali Press, 2015.

[23] H. Arief, Tumbuhan Obat dan Khasiatnya Seri 2. Jakarta: Penebar Swadaya, 2008.

[24] H. R. Sumarsono, Mengkritisi Aporisma Orang Jawa. Bekasi: Media Maxima, 2017.

[25] H. Geertz, The Javanese Family: A Study of Kinship and Socialization. Acls History E Book Project, 2014.

[26] F. S. Meutia, Kehamilan, Kelahiran, Perawatan Ibu dan Bayi dalam Konteks Budaya. Depok: UI Press, 1998.

[27] S.T. Widodo and K. Saddhono. "Petangan Tradition In Javanese Personal Naming Practice: An Ethnoliguistic Study." GEMA Online ${ }^{\circledR}$ J. of Lang. Stu. vol. 12 no. 4 pp 1165-1177, 2012 